\title{
The Olympic Games, nation branding, and public diplomacy in a post-pandemic world: Reflections on Tokyo 2020 and beyond
}

\author{
Yoav Dubinsky ${ }^{1}[$ ]
}

Revised: 6 November 2021 / Accepted: 13 December 2021

(c) The Author(s), under exclusive licence to Springer Nature Limited 2022

\begin{abstract}
The Tokyo 2020 Olympic Games were the first postponed Olympic Games, held in 2021, during an outbreak of a global pandemic, with strict restrictions and regulations and without international and domestic fans. Despite the challenges and the growing resistance, over 200 countries and delegations still saw value in participating in the most global event humanity holds. After covering or researching the Olympic Movement for over a decade including in four summer Olympic Games as an accredited journalist, the author shares ten reflections on nation branding and public diplomacy and the Tokyo 2020 Olympic Games on the following issues: (1) The Olympic Movement is entering a new era, (2) questionable legacy, (3) bypassing democracy, (4) athletes-to-people diplomacy is trending, (5) Brand America still an Olympic Superpower, (6) athletic competitions as nation branding battlefields, (7) manifestations of political conflicts, (8) rethinking cultural diplomacy, (9) global challenges, and (10) inevitable backlash. These reflections expand multidisciplinary literature on the Olympic Games, nation branding, and public diplomacy, and provide insights practitioners and decision-makers should consider when holding international sports competitions or other mega-events in a post-pandemic world.
\end{abstract}

Keywords Japan $\cdot$ Coronavirus $\cdot$ Country image $\cdot$ Sports diplomacy $\cdot$ Soft power

\section{Introduction}

The Tokyo 2020 Olympic Games were held in the summer of 2021 during a global pandemic, one year after their original date, and under very strict restrictions (Tokyo 2020a, b, c, d, e, f, g, 2021a). The Olympic Games have been a platform for hosting and participating countries to create an image that will lead to social, political, and economic goals (Dubinsky, 2019a, b). The use of nation branding and public diplomacy, goes back even further, to the ancient Olympic Games, and the different Greek city-states (Murray, 2018). In the twenty-first century, more countries and delegations are participating in the Olympic Games than officially recognized states by the United Nations (Dubinsky, 2019b). The Olympic Games are broadcasted to 220 countries and territories and are watched by billions (International Olympic Committee, 2021a). Big countries, small countries,

Yoav Dubinsky

yoavd@uoregon.edu

1 Instructor of Sports Business, Lundquist College of Business, University of Oregon, Anstett 298D, Eugene, OR 97403, USA democracies, autocracies, first-world, developing, and thirdworld countries, all see value in hosting or participating in the Olympics, making them the biggest show on Earth.

Fan (2010) defines a nation brand through "the total sum of all perceptions of a nation in the minds of international stakeholders, which may contain some of the following elements: people, place, culture / language, history, food, fashion, famous faces (celebrities), global brands and so on" (p. 98). A country's image is one of the outcomes of nation branding. Both nation branding and country image have been studied and researched through multiple lenses and fields (Buhmann \& Ingenhoff, 2015; Fan, 2010). According to Fan (2010), nation branding includes export branding known as country-of-origin or product-country-image, destination branding through place branding, political branding through public diplomacy, and nation branding, through national identity. According to Buhmann and Ingenhoff (2015), a country's image is analyzed through the fields of business management and nation branding, political science and public diplomacy, communication and different framing, and sociopsychology and national identity. Political scientist Joseph Nye (2004) coined the term soft power, referring to the ability of countries to achieve foreign goals through 
attraction and without the use of military force. Public diplomacy and culture are among the methods used in soft power to achieve foreign policy goals. While traditional definitions of public diplomacy emphasize communication with foreign publics that are ultimately tied to foreign policy (Cull, 2008), more contemporary definitions also see the significance in people-to-people diplomacy (Handelman, 2012) through informal interactions by non-governmental officials, and corporate-diplomacy (Ordeix-Rigo \& Durate, 2009) by corporations and firms in shaping a country's image. Buhmann and Ingenhoff (2010) developed a 4-dimensional model to evaluate a country's image, with the functional dimension about beliefs regarding the competencies and effectiveness of a country, the normative dimension pertaining to beliefs regarding a country's norms and values, the aesthetic dimension about beliefs regarding the attractiveness of a country as a cultural and scenic place, and the sympathetic dimension about general feelings towards a country.

For over a decade, the author has been covering and/or researching the Olympic Movement, including during the summer Olympic Games in Beijing, London, Rio de Janeiro, and Tokyo as an accredited journalist, publishing dozens of media articles, blogs, and academic manuscripts. In 2010, Professor Nicholas Cull published an invited article "Public diplomacy: Seven lessons for its future from its past" (Cull, 2010), discussing how the history of public diplomacy is relevant to the current communication-led age. This article is influenced by the structure and content of Cull's (2010) article, discussing the intersection between the Tokyo 2020 Olympic Games and different manifestations of nation branding, public diplomacy, country image, and related fields. The discussion is structured in a form of ten reflections that can provide value for practitioners and scholars when analyzing current and future use of sports events, mega-events, and of course future Olympic Games for nation branding, public diplomacy, and country image purposes in a post-pandemic world.

\section{The Olympic Movement is entering a new era}

The Tokyo Olympic Games were unprecedented and mark a beginning of a new era, not just because of the pandemic or being the first postponed Games, but because they, and future Games, offer a new evolution of the Olympic Movement. Dubinsky (2019b) divides the Modern Olympic Games into five different eras of nation branding and public diplomacy. The first era, the revival of the Olympic Games lasted between the first Modern Olympic Games in 1896 in Athens until the outbreak of World War I, during which the 1916 Olympic Games were canceled. In this era, the Games were relatively small, and at times hosted as part of another international event such as the World Fair or the British-Franco Exhibition. In the second era that lasted between World War I and World War II, countries started to recognize the potential of the Games, and new traditions were implemented, leading to Nazi Germany hosting the 1936 Berlin Olympic Games with clear nation branding and public diplomacy goals. During World War II the 1940 and 1944 Olympic Games were canceled. The political era of the Olympic Movement started after World War II and lasted until the end of the Cold War. After World War II the Olympic Movement became more international, and as the name of the era indicates, the era is characterized by countries, organizations, and individuals trying to achieve political goals through the Games. Examples included the Black Power Salute in Mexico City 1968, the Munich Massacre - the terror attack in which 11 Israeli athletes, coaches, and referees were kidnapped and murdered during the 1972 Olympic Games, the African boycott of the 1976 Olympic Games in Montreal, the American-led 60-countries boycott of Moscow 1980 after the Soviet Union invaded Afghanistan, and the retaliation of the Eastern Bloc with the boycott of the 1984 Olympic Games. The commercialized era from the end of the Cold War until the beginning of the twentyfirst century is characterized by the end of amateurism, the introduction of private sponsorships, the rise of television rights, and exposure of corruption scandals in the bidding process. In the legacy-oriented era, from the beginning of the twenty-first century until 2020, hosting countries and cities include long-term strategy, while local and international resistance is growing. While there are overlaps between the different eras, according to Dubinsky (2019b), each of these eras is unique as it adds a new dimension to the use of nation branding and public diplomacy through the Olympic Games. Despite identifying the eras before the outbreak of the COVID19 pandemic, Dubinsky (2019b), already recognizes a shift in the Olympic Movement, arguing that the 2020s "might signal if the Olympic movement is still focusing on legacy or will be starting a new Olympic era where countries will be targeting other opportunities to use the games to improve their images" (p. 37).

While every Olympic Games is different, the Tokyo Olympic Games is the first in a series of several Olympic Games that were either elected or hosted in an unprecedented way. Tokyo 2020 was held in 2021, being the first Olympic Games to be postponed, without international or local fans being able to attend the Games and with ample restrictions on athletes, media, and other accredited stakeholders (Kuhn, 2021; Tokyo 2020a, b, c, d, e, f, g, 2021a). The Games were held under a state of emergency, and as the coronavirus was not being contained, Japanese people and Tokyo residents repeatedly showed their objection to the Games in a variety of surveys (Kuhn, 2021). The following Games in 2024 in Paris and 2028 in Los Angeles were awarded together for 
the first time after multiple cities withdrew from the 2024 bid due to lack of local or governmental support (Dubinsky, 2019b; GamesBids, n.d.). Los Angeles was even the second choice of the United States Olympic and Paralympic Committee (USOPC), which originally chose Boston to bid to host in 2024 but had to change its candidate due to the growing opposition in Massachusetts. After awarding Paris and Los Angeles to host the 2024 and 2028 Olympic Games respectively, the International Olympic Committee (IOC) changed its bidding regulations and instead of competing bids, a special committee negotiates with candidate cities. Under the new regulations, a few days before the Opening Ceremony of Tokyo 2020, the IOC awarded Brisbane to host the 2032 Olympic Games (Zirin \& Boykoff, 2021).

Thus, while the future of the Olympic Games seems somewhat secure with the next three host cities already selected, the Olympic Movement is entering a new survivaloriented era in which it constantly has to change and adapt its policies amid ongoing threats and challenges. The IOC is often criticized for being extravagant and generating billions on the backs of local communities (Boykoff, 2016; Zimbalist, 2016; Zirin \& Boykoff, 2021), but a series of events leading to the Tokyo Olympic Games, and the decisions about future competitions, indicate that the Olympic Movement is more fragile than it might be seen. Despite having over 200 countries and delegations participating in the Games (International Olympic Committee, 2021a), when local communities get a chance to speak their minds, they usually vote against hosting the Games (Zirin \& Boykoff, 2021). The wave of activism (Abdul-Jabbar, 2021) and demand for free speech and to allow protests jeopardize the political neutrality of the Olympics. Of course, the pandemic caused the postponement of the Tokyo Olympic Games and the cancellation of the 2022 Youth Olympic Games (GamesBids, n.d), and is expected to continue to impact and challenge future Olympic Games. So far, the new era differentiates from previous ones and is characterized by the IOC making practical changes in policies, norms, and traditions, to ensure the survival of the Olympic Movement amid new challenges.

\section{Questionable legacy}

According to The Tokyo 2020 Organizing Committee of the Olympic and Paralympic Games (TOCOG), the total bid stage budget of hosting the Tokyo 2020 Olympic and Paralympic Games in 2021 was 15.4 billion US dollars (McCurry, 2021), \$2.8 billion more than if they would have not been postponed. Games which locals could not attend and could not generate revenues from international visitors. The Japanese government covered all the costs except $\$ 6.7$ billion. Thus, the legacy of the short-term and long-term legacies of the Games, remains questionable and the decision to host the Games has been criticized by international media and was protested locally in Japan (Nolympics LA, n.d; Zirin $\&$ Boykoff, 2021). Such a decision can hurt a country's normative dimension (Buhmann \& Ingenhoff, 2015). With that said, canceling the Olympics would have cost Japan USD16 billion (McCurry, 2021).

The narrative around Tokyo 2020 changed several times. Japan used the 1964 Tokyo Olympic Games to reposition the country's image from a devasted country after World War II, to a technological powerhouse through reconstruction of the city, introducing the bullet-train and using newly developed technology including satellite broadcasting for the first time in the Olympics (Abel, 2021; International Olympic Committee, 2021a). The original bid for the Games in 2013 focused on the recovery and reconstruction from the 2011 Tsunami and the nuclear disaster in Fukushima (Boykoff \& Gaffney, 2020; Tokyo 2021a, 2021b). Yet, in March 2020, when the Games were postponed due to the outbreak of the coronavirus, the narrative of the Games changed as well, for the Games to become a victory of humanity over a global pandemic. According to Cull (2010), effective public diplomacy needs to be credible and connected to policy. As the Japanese government was not able to contain the virus, the vaccination rates in Tokyo and Japan were lower than in the United States (USA) and Europe, Tokyo went into several states of emergency, and more and more restrictions were published, it became clear that the 2020 Olympic Games would not be a global celebration of a victory over the virus. Thus, the latest narrative focused on the importance of holding the Olympic Games despite the virus, and the significance of having the Games for the athletes. There was still a place in the Main Press Center (MPC) dedicated to recovery and reconstruction (Tokyo 2021a, 2021b), and measurements and restrictions were put to try and prevent further outbreaks of the virus. Movement was restricted, the ceremonies were less celebratory than in previous Olympic Games, and integration with the public was limited and at times prohibited (Tokyo 2021a, 2021b), all to secure that the Games could go on.

Japan was originally positioned relatively well to fight the virus. It is an island that could have taken measures such as New Zealand to prevent the virus from coming from abroad, the government took the virus seriously and took measurements early, the Japanese public is already accustomed to wearing masks and has a collectivist culture, and the Japanese technology is the most advanced in the world. Thus, falling behind on vaccinations, not being able to contain the virus, and holding the Olympic Games without fans and with ample restrictions, projected a problematic image of Japan's functional dimension (Buhmann \& Ingenhoff, 2015). TOCOG and the IOC try to market Tokyo 2020 to the world through the slogan "United by Emotion" (Tokyo 2020a, b, c, d, e, f, g, 2021c). Yet, such a motto also hides the sad 
reality that organizational failures prevented the world from being united in person and limited Japan from leveraging the Olympic Games to showcase its rich and diverse history and culture and use them for nation branding and public diplomacy, to achieve social, political, and economic goals.

\section{Bypassing democracy}

As mentioned, the Tokyo 2020 Olympic Games were the last summer Olympic Games which were awarded in a traditional bid, seven years in advance, after IOC members chose the Japanese capital over Istanbul and Madrid in the 125th IOC Session in 2013 (GamesBids, n.d). In the same session, the IOC also elected Thomas Bach as the organization's ninth president, succeeding Jacque Rogge. One of Bach's first initiatives as IOC President was to review and revise the Olympic Movement, through what was defined as "Agenda 2020 " - a list of 40 recommendations and guidelines of how to improve the Olympic Movement (International Olympic Committee, 2014). As much of the criticism over the IOC was about the costly bidding process and the delivery of the Games, some potential reforms were suggested in the agenda 2020 Recommendations. Yet, while the IOC was projecting optimism, the following bids during Bach's Presidency continued to show resistance and lack of trust by local populations (Zirin \& Boykoff, 2021). During the bid for the 2022 Winter Olympic Games, either due to lack of governmental support or due to lack of public support, Stockholm, Warsaw, Krakow, and Oslo, withdrew from the bid, leaving only Almaty from Kazakhstan and Beijing from China as the only candidate (GamesBids, n.d; Zimbalist, 2016). Munich, who bid for the 2018 Winter Olympic Games, did not enter the bid for 2022 after the people of Bavaria voted against hosting the Games in a referendum (Zimbalist, 2016). The result in the Munich referendum might also be seen as a vote of lack of confidence by the German people against the German President of the IOC.

As the bid for the 2022 Winter Olympic Games started before the implementation of Agenda 2020, there was hope in the IOC that the bid for the 2024 Olympic Games will be different under the new flexible recommendations. Yet, despite a promising start, bids from Budapest, Rome, Boston, and Hamburg all failed to get to the finish line due to lack of public or political support (GamesBids, n.d.; Zirin \& Boykoff, 2021). Once again Bach received an international humiliation from the people of Germany, this time in the Hamburg bid referendum. The USOPC chose Boston after a preliminary bid process as the American candidate city for the 2024 Olympic Games, but after a growing opposition in Massachusetts, the bid collapsed. Going back to the lab again, the Americans chose runner-up Los Angeles to bid to host the Games for the third time, without going through a referendum. Despite Agenda 2020, once again the IOC found itself in a familiar place where when the public has power to vote and influence, people chose not to host the Games, leaving only two candidate cities for the 2024 Olympic Games - Paris and Los Angeles - two global cities who have each hosted the Olympic Games twice before and regularly host mega-sport events. Recognizing the problem but also the opportunity, in an unprecedented step, the IOC decided to award both Paris and Los Angeles to host the 2024 and 2028 Olympic Games respectively, with the French capital being the first. Thus, two major cities in two of the most democratic countries in the world were awarded to host the Olympic Games in a vote without an opposing candidate. While there was at least some kind of a bid process for the 2024 Olympic Games, there was no other city competing for the 2028 Olympic Games as the winner was awarded 11 years in advance.

Despite the problematic process, selecting Paris to host in 2024 and Los Angeles in 2028, was supposed to bring some stability to the IOC, knowing that the future of the Olympic Movement is secured for the 2020s. Yet, choosing a hosting city 11 years in advance turned out to be problematic. Due to the outbreak of COVID19 and the threats of several countries to withdraw from the Games in 2020, the IOC and TOCOG were not able to proceed as planned. Initially, the Games were postponed by a year, but as the pandemic escalated and Japan and Tokyo went in-and-out of states of emergency, the opposition to hosting even the postponed Games became stronger by the Japanese people, local companies, and even Games-related stakeholders. With Paris already being in the advanced stages of the preparations and having Los Angeles awarded the 2028 Olympic Games, further postponement of the Tokyo Olympic Games was not a publicly discussed option. This situation resulted in the Japanese people paying to host a global celebration during a deadly pandemic without even being able to attend the party as the Games were held without fans.

With resistance groups against the Olympic Games growing stronger and louder (Boykoff \& Gaffney, 2020; Zirin \& Boykoff, 2021), the IOC changed its selection policies, and instead of competing bids, a special commission enters in direct negotiations with cities that are interested in hosting. A process that many see as non-democratic and not transparent. Despite the chaos around the Tokyo Olympic Games, the IOC decided once again to choose a hosting city 11 years in advance, awarding Brisbane the rights to host the Olympic Games in 2032 (Zirin \& Boykoff, 2021). While other cities might have been interested in hosting the Games, only a small committee of people decided that the Australian city will be the one entering a dialogue, before bringing the vote for approval before all the IOC members. Thus, with the growing resistance by local communities, with non-Olympic NGOs becoming stronger, and with the 
IOC constantly changing its rules and regulations, transparency and democracy are becoming a burden and a limitation on the Olympic Movement (Zirin \& Boykoff, 2021).

\section{Athletes-to-people diplomacy is trending}

From a people-to-people diplomacy perspective (Handelman, 2012), athletes could be a resource for sports diplomacy (Abdi et al., 2019) through their competitions, behaviors, and athletic success, protecting their country's image to diverse international audiences and effecting the sympathetic dimension of a country (Buhmann \& Ingenhoff, 2015). In the context of the Olympic Movement, examples include Jesse Owens defying the racist ideology of Nazi Germany, Abebe Bikila winning the Marathon in Rome barefoot and starting the glorious legacy of long-running in Africa, Nadia Comaneci exposing Romanian gymnastics and breaking barriers through the Cold War, to Usain Bolt and Jamaican sprinters in the twenty-first century (Dubinsky, 2019a). Perhaps contrary to the decline of the power of the people, Tokyo 2020 also signifies a rise in the power of the athletes. Tokyo 2020 was the first Olympic Games held after the COVID19 pandemic, which did not only cause a health challenge around the world but was followed by a wave of social activism, especially after the murder of African American George Floyd by a police officer in Minnesota (Abdul-Jabbar, 2021).

Yet, to fully understand the events, one needs to go back to shortly after the 2016 Olympic Games in Rio de Janeiro, when American football player Colin Kaepernick started kneeling in pre-season football games as a protest against racism and police brutality in the USA (Cooper et al., 2019). Kaepernick's actions were followed by numerous protests in not just in American sports, but in international competitions as well including former Olympic champion Megan Rapinoe kneeling during the American national anthem in a friendly international competition before she was instructed to stop, and Olympic athletes protesting on the podium during the 2019 Pan-American Games, which resulted with the USOPC reprimanding them (Dance, 2020; Zaccardi, 2020). Professor Harry Edwards, one of the leading voices on athlete's activism and a mentor to Tommie Smith and John Carlos who protested racial injustice in America during the 1968 Olympic Games in Mexico City, classified the series of protests as the fourth wave of athletes' activism (Cooper et al., 2019). Unlike in previous waves, this wave was characterized by athletes with social, political, and economic power, who used social media to bypass traditional white establishments and directly correspond with their followers. Following the murder of George Floyd in 2020, the wave of activism spread to more sports, more athletes, more minority groups, and beyond the boundaries of the USA. As a result of the growth of activism, several American sports organizations that originally objected to the protests changed their policies and even apologized to their athletes (Zaccari, 2020).

Leading up to the Tokyo 2020 Olympic Games, Thomas Bach and the IOC, repeatedly emphasized the importance of Rule 50 in the Olympic Charter. According to the rule: "No kind of demonstration or political, religious or racial propaganda is permitted in any Olympic sites, venues or other areas" (IOC, 2020, p. 90). When Smith and Carlos protested in 1968, Avery Brundage, the American President of the IOC instructed the USOC to send the athletes back. Smith and Carlos were scrutinized and suffered from racism and financial difficulties after their return (Cooper et al., 2019; Zimbalist, 2016). It took decades before they were accepted as national heroes, and in 2019 they were finally introduced into the USOPC Hall of Fame. The shift in the approach towards athletes' activism in the USA, also manifested through the Tokyo 2020 Olympic Games as the IOC relaxed some of the restrictions (International Olympic Committee, 2021d). While the IOC continued to emphasize the need for political neutral Games, athletes were allowed to kneel before competitions, which happened in several soccer games and other sports (Abdul-Jabbar, 2021). While the fear that relaxing the regulations about protesting will result in a variety of political causes raised by athletes, there were only a handful of athletes who tested the water and were not sanctioned for it. Perhaps the most visible protest was done by gay African American silver medalist Raven Saunders, who used the time on the podium to create an $\mathrm{X}$ with her hands symbolizing "the intersection of where all people who are oppressed meet" (Bates, 2021). American Fencer Race Imboden and American hammer thrower Gwen Berry who protested during the 2019 Pan American Games, made modest protests during the Tokyo Olympic Games as well (Abdul-Jabbar, 2021). Neither the IOC nor the USOPC sanctioned the athletes for the gestures, which is a significant difference from the response both organizations had to the protest of Smith and Carlos in 1968.

While the Black Lives Matter movement was significant for activism against racism, the \#MeToo movement also influenced reforms and more vocal and opinionated athletes. The growing importance of inclusion and gender in sports, also manifested with a transgender athlete from New Zealand and a trans-nonbinary athlete in Canada competing in the Tokyo Olympic Games (Abdul-Jabbar, 2021), changing not only perceptions on gender fluidity but branding their countries as progressive and democratic. Perhaps the most significant female athlete in the two most significant female athletes in the Games in terms of social change was American gymnast Simone Biles and Japanese tennis player Naomi Osaka using sports to raise awareness for mental health (Abdul-Jabbar, 2021). 
One of the most horrific scandals in sports history was revealed just after the 2016 Olympic Games, as hundreds of American gymnasts testified against Dr. Larry Nassar for sexual assaults during his roles at the USOC, USA Gymnastics, and Michigan State University (Kwiatkowski, 2021). Simone Biles, who was assaulted by Nassar, continued to compete and represented Team USA in Tokyo as well. During the Olympics Biles withdrew in the middle of the team competition and from four of the five individual finals she qualified for because of mental health reasons. While several athletes have been talking in the past about mental health, the Tokyo 2020 Olympic Games are unique as Biles decided to prioritize her mental health over competing. Biles' decision came a few months after Naomi Osaka started withdrawing from Grand Slam tennis tournaments, speaking on mental health reasons as well. The acceptance of athletes prioritizing their health over taking part in the competitions, also shows a culture shift because of a variety of civil rights movements. From a nation branding, public diplomacy, and people-to-people diplomacy perspectives, it is also evident that these shifts of culture were ignited or led by American athletes and American culture.

Lastly, when discussing cultural shifts, the new generation of athletes and fans also manifests through newly introduced sports, that pertain to urban cultures, such as skateboarding and climbing, as the IOC is trying to attract younger audiences. In skateboarding, some of the medalists were young teenagers at the age of 13 , who are already social media influencers. While some celebrate the change, there is also a growing criticism against the pressure put on children to become elite athletes at such a young age by their environment, including the sports federations and even governments. With the growing awareness of mental health and burnout, and with the constant use of social media, these issues will continue to challenge the Olympic Movement.

\section{Brand America still an Olympic superpower}

The 1984, Los Angeles Olympic Games changed the Olympic Movement after several Games in which international politics overshadowed the competitions. Being privately funded, Los Angeles 1984 started the commercial era of the Olympic Movement, leading to the TOP sponsorship program in 1985 and to the official abolishment of amateurism in the 1988 Seoul Olympic Games (Dubinsky 2019a; $2019 b)$. That, along with the end of the Cold War, gave the USA significant influence in the Olympic Movement. With broadcasting rights being the most profitable stream of revenues (International Olympic Committee, 2021a) and most television revenues coming from North America and the USA, the American influence of the Olympic Movement and the Olympic Games manifest in a variety of ways.
Some of the critics over hosting the 2020 Olympic Games argued that the organizers folded under pressure from TV rights holders and sponsors, with several of these stakeholders being American. Furthermore, Los Angeles was awarded the 2028 Olympic Games 11 years in advance, which potentially blocked any chance of further postponing the Tokyo Games as well.

The influence of American television rights holders also manifested in scheduling events according to American prime time. For example, the swimming finals were held in the morning and not in Japanese prime time. The basketball final was also held in the morning, hours before the bronzemedal match. Originally the women's football (soccer) final was scheduled to be held in the morning despite the heat in Tokyo, but after the USWNT did not qualify, the organizing committee agreed to the requests of Canada and Sweden to hold the final in the evening in Yokohama.

Despite having a questionable ethical Olympic history, the USOPC or American governing bodies are very rarely sanctioned by the IOC. After leading a 60-countries boycott of the 1980 Moscow Olympic Games from political reasons, not only the USA was not suspended from the Olympic Movement, but Los Angeles was allowed to fund the 1984 Games through private sponsors (Dubinsky, 2019b). Just as a point of reference, after North Korea did not send a delegation for the Tokyo 2020 Olympic Games, the IOC suspended the Olympic Committee of North Korea from participating in the 2022 Beijing Winter Olympic Games (Morgan, 2021). Another famous scandal in which the Americans suffered almost no consequences was the corruption around the bid for the 2002 Winter Olympic Games in Salt Lake City, where IOC members were bribed by bid-related stakeholders (Boykoff, 2016). Yet, while the IOC did reform some of its policies and suspended a few members, Salt Lake City was not stripped from hosting the Games. Over the years, several American athletes have been caught doping in some of the most notorious doping scandals, such as Marion Jones as part of the BALCO doping scandal (CNN Editorial Research, 2021) and Lance Armstrong and the U.S. Postal Service Pro Cycling Team who as the U.S. Anti-Doping Agency (USADA) defined "ran the most sophisticated, professionalized and successful doping program that sport has ever seen" (USADA, 2021). More recently, the Nike Oregon Project, a project promoting long-runs supported by Nike - the official outfitter of Team USA - was closed after USADA banned coach Alberto Salazar for doping violations (Grez, 2019). Yet, while Russian athletes were forced to compete under their Olympic Committee and not under the Russian flag for systematic doping scandal, American sports governing bodies such as the USOPC or USA Track \& Field did not suffer international consequences. The USOPC or USA Gymnastics also did not suffer international sanctions after the sexual abuse scandal in which former Team USA 
doctor Larry Nassar sexually abused hundreds of gymnasts over decades, including Olympic champions (Kwiatkowski, 2021). According to the 2020 version of the Olympic Charter (International Olympic Committee, 2020), part of the mission of the IOC is "to promote safe sport and the protection of athletes from all forms of harassment and abuse" (p. 17). Yet, despite the systematic sexual abuse scandal in the USOPC and USA Gymnastics, these organizations were not retroactively suspended from future Olympic Games, which eventually enabled the USA to top of the medal table podium (Tokyo 2020, n.d) much thanks to the two gold medals won in women's gymnastics.

\section{Athletic competitions as nation branding battlefields}

The athletic field has always been a stage for nation branding and public diplomacy battlefield through participation and performance (Dubinsky, 2019a; 2019b). Overall, 206 delegations competed in the Tokyo Olympic Games, including a refugee delegation, and the National Olympic Committee of Russia (Tokyo 2020a, b, c, d, e, f, g, 2021d). The only country that did not send athletes to compete in Tokyo was North Korea (Morgan, 2021). For the third straight summer Olympic Games, the USA finished first in the medal table, winning the most gold medals and overall medals (Tokyo 2020a, b, c, d, e, f, g, n.d). Much like in 2016, once again American women won most of these medals, demonstrating the significance of Title IX in the American system, and in American sports diplomacy. Some of the athletes who stared in Tokyo participated in diplomatic initiatives as envoys of the US Department of State, including two of the stars of the Olympic Games; Allison Felix, who won a gold and a bronze medal in Tokyo, become the track and field athlete with most Olympic medals in the history, and Swimmer Katie Ledecky, who won three gold medals and two bronze ones, becoming the most decorated female Olympic swimmer (Bureau of Educational and Cultural Affairs, n.d). Yet, the American dominance was much less significant than in previous Games as only on the day of the closing ceremony did the USA pass China in the gold medal ranking (Tokyo 2020a, b, c, d, e, f, g, n.d). Through most of the Games, the Chinese anthem was the most played anthem on the podiums, especially in dominated events such as table tennis, weightlifting, and diving.

Aligning national goals with athletic success led to different attempts to improve the country's rankings, varying from specializing in specific disciplines, through naturalizing athletes who were born in other countries, to different forms of cheating including systematic doping going back to East Germany and the Soviet Union during the Cold War (Pigman, 2014; Zimbalist, 2016). In Tokyo 2020, the Russians were not allowed to compete under the Russian national flag due to a government-led doping scandal, and when athletes won gold medals, instead of the Russian national anthem, Tchaikovsky's Piano Concerto No. 1 was played, demonstrating at least part of Russia's cultural depth. Much like many other hosting countries, Japan also enjoyed athletic success finishing third in the gold medal ranking, dominating some of the country's popular sports such as judo where Japanese athletes won 9 gold medals and 12 overall medals from 15 possibilities in the historic venue the Nippon Budokan (Tokyo 2020a, b, c, d, e, f, g, n.d). Japan also won gold medals in some of the new or returning disciplines such as baseball and softball, three gold medals in skateboard, and one in karate.

Some countries specialize in specific disciplines or specific sports (Dubinsky, 2019a). In Tokyo 2020, Jamaican women and Caribbean athletes excelled in the sprints, while athletes from Kenya, Uganda, and Ethiopia, excel in the long runs (Tokyo 2020a, b, c, d, e, f, g, n.d). Perhaps one of the most extraordinary performances in the Tokyo Olympic Games was by Ethiopian-born Dutch athlete Sifan Hassan, winning gold medals in $10,000 \mathrm{~m}$ and $5000 \mathrm{~m}$, and a bronze medal in $1500 \mathrm{~m}$. Australian women dominated the pool winning 8 gold medals, led by Emma McKeon who won four gold medals and three bronze ones.

The Tokyo Olympic Games had two records of 88 different countries winning at least one medal, and 63 countries winning gold. Turkmenistan, San Marino, and Burkina Faso won their first Olympic medals, having their flags risen during the medal ceremony for the first time. The Philippines, Bermuda, and Qatar won their first gold medals, having their anthem played on the podium for the first time (Fowler, 2021). While Qatar's investment in sports has often been criticized for naturalization, sports-washing, or corruption (Zimbalist, 2016), a very different image of the country was projected when Qatari high jumper Mustaz Essa Barshim and Gianmarco Tamberi from Italy were tied at the end of the event, yet instead of having a jump-off, they both decided to share the top of the podium with each getting a gold medal (Abdul-Jabbar, 2021; Fowler, 2021), giving the Games an emotional feel-good moment.

\section{Manifestations of political conflicts}

While the IOC did give more flexibility to athletes to protests, the IOC still prohibits political boycotts through athletic competitions. The political manifestations and boycotts in the twenty-first century have been more subtle or even silent compared to the mass boycotts of the 1976, 1980 and 1984 Olympic Games (Dubinsky, 2019a). Yet, there are still political manifestations in the Olympic Games, such as athletes from certain Arab and Muslim 
countries forced by their governments to withdraw from competing against Israelis under the guise of an injury (Dubinsky \& Dzikus, 2019). Before the Tokyo 2020 Olympic Games, the Iranian Judo Federation was suspended for continuing with such policies (Palmer, 2021). Perhaps the most astonishing case was of judoka Saeid Mollaei, a former Iranian world champion who publicly criticized Iran's policies after being forced to lose a match to avoid facing an Israeli. As a result, Mullaei said he was afraid to return to Iran, and fled to Europe, before officially becoming a citizen of Mongolia. He won a silver medal in Tokyo (Trouillard, 2021). There were two suspected silent boycotts in judo, with athletes from Algeria and Sudan. The Algerian athlete and his coach were suspended for 10 years by the International Judo Federation because of the incident (Reuters Staff, 2021). On the other hand, for the first time, an athlete from Saudi Arabia competed against Israeli Raz Hershko (Palmer, 2021). This should also be looked at through the lenses of the growing criticism of Israeli policies against the Palestinians, and the growing support of international athletes and of Black Lives Matter with the Palestinian cause. Another issue related to the Israeli-Palestinian conflict that pertains to public diplomacy and the Olympic Games is the demand to officially commemorate the 11 Israeli athletes, coaches, and referees that were murdered in Munich during the 1972 Olympic Games (Dubinsky \& Dzikus, 2019). For decades the families of the victims have been demanding that the 11 Munich Victims will be commemorated in the opening ceremony, and in Tokyo 2020 for the first time they were mentioned as part of a moment of silence.

Much like in the 2016 Rio de Janeiro Olympic Games, Tokyo 2020 also included a delegation of refugees. The IOC Refugee Olympic Team included 29 athletes from 11 host countries, competing in 12 sports (International Olympic Committee, 2021b). Emphasizing the significance of the team, the delegation marched second in the opening ceremony, following Greece who always marches first. During the Games Belarusian athlete Krysttsina Tsimanouskaya sought help from the IOC through social media after being taken to the airport for criticizing her government but refused to board the flight (Dunbar, 2021). Eventually, the athlete was granted a Polish visa after seeking refuge from Belarusian authorities. Such an example demonstrates the political significance countries see in participating in the Olympic Games, the challenge of containing freedom of speech and criticism in different cultures and regimes, some of the diplomatic roles the IOC is taking as a non-governmental international organization, and the potential impact on the normative and sympathetic dimension of a country's image (Buhmann \& Ingenhoff, 2015) through the framing of a country by international media.

\section{Rethinking cultural diplomacy}

The Olympic Games have been a platform for countries to improve the aesthetic dimensions (Buhmann \& Ingenhoff, 2015) of their images through the exposure of their culture, heritage, and tourism attractions. Yet, without international fans arriving, much of these opportunities are either lost or depend on other gatekeepers such as the media. However, in the Tokyo 2020a, b, c, d, e, f, g Olympic Games, even accredited journalists who were able to attend and cover the Games were under strict movement restrictions due to the pandemic. During the first months of 2021, the IOC and TOCOG published three versions of The Playbook - a book of guidelines for different stakeholders, with each version having more restrictions (Tokyo 2020a, b, c, d, e, f, $\mathrm{g}, 2021 \mathrm{a})$. As explained in the 3rd version of the Playbook for media, international media were under quarantine for their first 14 days in Japan, during which they were followed through mobile applications and were only allowed to go to Olympic venues and use Olympic-sanctioned transportation (Tokyo 2020a, b, c, d, e, f, g, 2021a). This meant that even the media covering the Olympic Games were not allowed to visit tourism attractions or interact with locals during most of the Games. The windows of possibilities to capitalize on cultural diplomacy and or on destination branding (Fan, 2010) and enrich the aesthetic and sympathetic dimensions (Buhmann \& Ingenhoff, 2015) of Japan's image through inperson activities during the Olympic Games were extremely limited.

Traditionally, hosting and participating countries try to capitalize on Olympic Games through hosting cultural events. Some participating countries have an "Olympic House" in which they host different stakeholders, and expose some of their food, music, and culture when hosting events, celebrations, or watch-parties open to international fans traveling to the Olympic Games (Gordon, 2016). As no international fans were traveling to Tokyo, Olympic Houses were not used for nation branding and public diplomacy purposes as used in previous Games. Hosting countries and cities usually have a Cultural Olympiad during the Olympic Games, which includes education collaborations with schools, and different exhibitions and programs. TOCOG, the Japanese Government, and the city of Tokyo did hold several activities or events, including the Nippon Festival and The Olympic Agora (Tokyo 2020a, b, c, d, e, f, g, 2021e, 2021f). While some of the content was also available online, the main issue remained that through most of the Games because of the restrictions the only people who could attend were local Japanese, thus the impact on foreign publics was very limited.

Perhaps the events where the intersection between sports, culture, and diplomacy is the strongest are the 
opening and closing ceremonies. These ceremonies allow the hosting country to showcase its soft power by exposing its history and culture (Arning, 2013). In the closing ceremony for Rio de Janeiro 2016, during the section dedicated to the next hosting city Tokyo, Shinzo Abe, then the Prime Minister of Japan, appeared dressed as Super Mario (Rich, 2016). While the ceremonies in Tokyo did expose some Japanese traditions, such light-headed references rarely appeared. The opening ceremony was described in words such as "somber", "minimalist" (Akbar, 2021), "subdued" (Fadel, 2021), and even "depressing as hell" (Fallon, 2021). The closing ceremony traditionally has a celebratory theme, yet again was described as "somber", but also with "grace" (Ronay, 2021). With no fans, a minimal number of athletes in the stadium, and with increasing COVID19 cases, the use of the ceremonies as a soft power tool to improve the aesthetic dimension and sympathetic dimension (Buhmann \& Ingenhoff, 2015) of Japan was limited.

\section{Global challenges}

For the Tokyo Olympic Games to go ahead almost every stakeholder needed to compromise. From athletes needing to adjust their preparations to media needing to accept restrictions of freedom of the press, to the Japanese people who were not allowed to attend the Games, all stakeholders had to adjust to a new reality for the Games to happen, and willingly or not, they did (Tokyo 2020a, b, c, d, e, f, g, 2021a). Thus, from a macro-perspective over 200 countries and delegations saw more value in participating in the Tokyo 2020 Olympic Games and accepting restricting rules, than withdrawing. The IOC and TOCOG used slogans such as "United by Emotion", or even adjusted the Olympic Moto to "Faster, Higher, Stronger - Together" (Tokyo 2020a, b, c, d, e, f, g, 2021c), reinforcing that message. Whether the cost was worth it or not, all stakeholders saw enough value in having the Games happening to collaborate.

An even larger global challenge than the pandemic that pertains to every country and person on this planet is the environment and global warming. Each hosting city tries to emphasize in its bidding process how hosting the Olympic Games will improve the quality of life, or how sustainable the organization will be. In 2021 the IOC introduced Olympic Agenda $2020+5$, adding 15 recommendations to the original 40, including further emphasizing sustainability and the environment (International Olympic Committee, 2021e). Yet, the practical challenges often overshadow such plans, and the IOC is often accused of greenwashing (Boykoff, 2016; Boykoff \& Gaffney, 2020). As mentioned earlier, the Tokyo 2020 was originally framed as recovery and reconstruction games from a natural disaster and the organization tried to demonstrate having sustainable policies that protect the environment. Examples include using electric and even automatic cars, temporary venues, and even awarding recycled medals. Global warming creates a challenge in every continent, regardless of the economic status of the countries. Organizing committees and the IOC publish their sustainable activities of policies, but much of the growing criticism against the IOC is hosting Olympic Games in non-sustainable ways, damaging the environment (Boykoff, 2016; Zimbalist, 2016) and greenwashing (Boykoff \& Gaffney, 2020). Perhaps if the Olympic Games would be in jeopardy of cancellation because of the environment, that would lead to a more united front against one of the world's greatest challenges.

\section{Inevitable backlash}

There was no shortage of criticism against the Japanese government, the organizing committee, and the IOC about the Tokyo 2020 Olympic Games (Boykoff \& Gaffney, 2020). The majority of the people of Tokyo did not support hosting the Games in the summer of 2021, sponsors and partners moderated their presence, there was a corruption scandal around the Games, numerous high-level officials resigned for various reasons, and protests against the Olympics followed the torch relay and occurred during the Games including outside the opening ceremony (Boykoff \& Gaffney, 2020; Rosenberg, 2021). Much of the criticism focused on lack of transparency, misinformation, or misuse of data. The IOC and the organizing committee took pride in holding over 675,000 tests and having a $0.02 \%$ positivity rate (Burke, 2021), but still, there were over 500 positive COVID19 cases related to the Olympic Games, including the lambda variant (The Japan Times, 2021). On July 23, the day of the opening ceremony, the Tokyo Media Center reported 1359 new daily cases in Tokyo (TMC, 2021). Within a few days after the Olympic Games, the daily cases have risen to over 5,000 (Staff Report, 2021).

The local backlash against hosting the Tokyo 2020 Olympic Games also impacted Japan's corporate diplomacy. With the country being associated as a technological powerhouse, there were several Japanese TOP sponsors (Abel, 2021; International Olympic Committee, 2021a). Toyota for example provided a self-driving bus in the Olympic Village and hybrid electric cars for different stakeholders as part of a sustainability effort. Panasonic also provided tech services in the MPC and other Olympic venues. Yet, despite investing hundreds of millions in the sponsorship agreements, after TOCOG announced that the Olympic Games will be held without fans, Toyota scaled back its advertising efforts in Japan and Panasonic announced that the CEO of the company will not attend the opening ceremony (Kuhn, 2021). 
The backlash against the Olympic Games has been gaining momentum over the years (Zimbalist, 2016). NOlympics groups emerge in almost every candidate, bidding, or hosting cities, protesting against hosting the Games, demanding transparency, and emphasizing how the Games will hurt local communities (Nolympics LA, n.d). Scholars have also been criticizing the Olympic Movement, questioning if the Olympic Games in their current form should even go ahead (Boykoff, 2016; Zimbalist, 2016). While the IOC does not necessarily depend on the support of local communities, the mayors and governments in the hosting cities and countries do need the people's support in upcoming elections. Thus, in countries such as France, the USA, and Australia, and next hosting cities such as Paris, Los Angeles, and Brisbane, ignoring the voices of the public can have a personal price.

\section{Conclusion}

The reflections in this article emphasize the ongoing importance of the Olympic Games for nation branding and public diplomacy, as, despite all the challenges, over 200 countries and delegations still see the importance of taking part in the most global event humanity holds (Tokyo 2020a, b, c, d, e, f, g, 2021d). Tokyo 2020 showed that despite the pandemic and the related health risks, almost every country on Earth sees some value in taking part in the Olympic Games. Yet, the Olympic Movement is also under extreme scrutiny and the resistance is likely to keep growing. The Olympic Movement is changing, facing unprecedented backlash from local communities and different pressure groups, leading it to try and bypass dependency on the public's opinion. The reflections in this article contribute both to practitioners and scholars working in the field of nation branding, public diplomacy, and sports. Practitioners, decision-makers, and different stakeholders trying to capitalize on mega-events and future Olympic Games should consider the reflections in this article when setting organizational policies. For scholars, this article enhances the growing multidisciplinary literature on the intersections between nation branding, public diplomacy, and the Olympic Games.

In terms of limitations, delimitations, and future research, the article did not conduct a cause-and-effect study on the projected image of Japan. That will require a more systematic research design focusing on attitudes towards Japan's image. The article analyzes mostly the Tokyo 2020 Olympic Games, and not the Paralympic Games. The Tokyo 2020 Paralympic Games pose a different challenge, and have other intersections with nation branding and public diplomacy, including countries withdrawing from the event due to the health risks of the pandemic, arranging an Afghan women's team while the USA withdrew from Afghanistan and the Taliban took over, China dominated the medal table, New
Zealand wheelchair rugby team doing the Haka dance before competitions, Japanese TOP sponsor Toyota pulling out the use of automatic buses in the Olympic Village after one of the vehicles hit a visually impaired athlete, or Japan's prime minister Yoshida Suga announcing he will not run for partly leadership and will step down after less than a year in office.

The article identifies and discusses a variety of stakeholders that play significant roles in shaping nation branding and public diplomacy, including countries, NGOs, athletes, sponsors, broadcasters, and local and international communities. The Olympic Movement is entering a new era which is described in the article as the "survival-oriented era". The Tokyo 2020 Olympic Games showed that the pandemic and the rise of social activism are posing challenges the Olympic Movement has not resolved, and that backlash is growing. With that said, Tokyo 2020 also presented some of the potential short-term solutions that IOC and TOCOG used, the significance of international media to ensure the survival of the Games, and the role of digital platforms for reproducing the Olympic spirit. Further research should analyze the short-term and long-term impacts of the global pandemic on the different stakeholders using sports for nation branding and public diplomacy and explore alternative ways of hosting Olympic Games and other mega-events amid the growing backlash and challenges.

\section{Declarations}

Conflict of interest The author states that there is no conflict of interest.

\section{References}

Abdi, K., M. Talebpour, J. Fullerton, M.J. Ranjkesh, and H.J. Nooghabi. 2019. Identifying sports diplomacy resources as soft power tools. Place Branding \&amp; Public Diplomacy 15 (3): 147-155. https://doi.org/10.1057/s41254-019-00115-9.

Abdul-Jabbar, K. (August 8, 2021). Kareem Abdul-Jabbar: What I learned watching the Tokyo Games. The Hollywood Reporter. Retrieved from https://www.hollywoodreporter.com/tv/tv-news/ kareem-abdul-jabbar-olympics-lessons-1234994649/.

Abel, J.R. 2021. Technologies of Cold War diplomacy: Transforming postwar Japan. Technology and Culture 62 (1): 128-155. https:// doi.org/10.1353/tech.2021.0005.

Akbar, A. (July 23, 2021). Tokyo Olympic opening ceremony: toil and mourning bloom into sparkling extravaganza. The Guardian. Retrieved from https://www.theguardian.com/sport/2021/jul/23/ tokyo-olympic-opening-ceremony.

Arning, C. 2013. Soft power, ideology and symbolic manipulation in Summer Olympic Games opening ceremonies: A semiotic analysis. Social Semiotics 23: 523-544

Boykoff, J. 2016. Power games: A political history of the Olympics. New York: Verso.

Boykoff, J., and C. Gaffney. 2020. The Tokyo 2020 games and the end of Olympic history. Capitalism Nature Socialism 31 (2): 1-19. https://doi.org/10.1080/10455752.2020.1738053. 
Buhmann, A., and D. Ingenhoff. 2015. The 4D Model of the country image: An integrative approach from the perspective of communication management. The International Communication Gazette 77: $102-124$.

Bureau of Educational and Cultural Affairs. (n.d.). Sports Envoy. United States Department of State. Retrieved from https://eca. state.gov/sports-diplomacy/sports-envoy.

Burke, P. (August 11, 2021). Tokyo 2020-related COVID-19 cases top 500 as Japanese capital again reports more than 4,000 new infections. Inside the Games. Retrieved from https://www.insid ethegames.biz/articles/1111525/tokyo-2020-covid-cases-top-500.

Close, D., Barnes, T., \& Najim, A. (July 24, 2021). Algerian Olympian withdraws from Games due to potential matchup with Israeli competitor. $C N N$. Retrieved from https://www.cnn.com/2021/07/24/ sport/algerian-olympian-withdrawal-israel-intl/index.html.

CNN Editorial Research. (April 15, 2021). BALCO Fast Facts. CNN. Retrieved from https://www.cnn.com/2013/10/31/us/balco-fastfacts/index.html.

Cooper, J.N., C. Macaulay, and S.S. Rodriguez. 2019. Race and resistance: A typology of African American sport activism. International Review for the Sociology of Sport 54 (2): 151-181. https:// doi.org/10.1177/1012690217718170.

Cull, N.J. 2008. Public diplomacy: Taxonomies and histories. ANNALS of the American Academy of Political Science 616 (1): 31-54.

Cull, N.J. 2010. Public diplomacy: Severn lessons for its future from its past. Place Branding and Public Diplomacy 6: 11-17. https:// doi.org/10.1057/pb.2010.4.

Dance, B. (January 13, 2020). 'We shouldn't be silenced': IOC's protest ban cops backlash from athletes. FOX Sports. Retrieved from https://www.foxsports.com.au/olympics/we-shouldnt-be-silencediocs-protest-ban-cops-backlash-from-athletes/news-story/ca1e0 cb83ef78088d00d129b3f02743c

Dubinsky, Y. 2019a. From soft power to sports diplomacy: A theoretical and conceptual discussion. Place Branding and Public Diplomacy 15: 154-164. https://doi.org/10.1057/s41254-019-00116-8.

Dubinsky, Y. 2019b. Analyzing the roles of country image, nation branding, and public diplomacy through the evolution of the modern Olympic movement. Physical Culture and Sport Studies and Research 84 (1): 27-40. https://doi.org/10.2478/pcssr-2019-0024.

Dubinsky, Y., and L. Dzikus. 2019. Israel's country image in the 2016 Olympic Games. Place Branding and Public Diplomacy 15: 173 184. https://doi.org/10.1057/s41254-018-0105-y.

Dunbar, G. (August 2, 2021). Poland grants visa to Belarus Olympian who fears for safety. AP. Retrieved from https://apnews.com/artic le/2020-tokyo-olympics-krystsina-tsimanouskaya-belarus-asylum-8467db47e3dc84a0719e76a0eb0481a2.

Fadel, L. (July 23, 2021). With a subdued Opening Ceremony, the Tokyo Summer Olympics have officially kicked off. $n p r$. Retrieved from https://www.npr.org/2021/07/23/1019892681/with-a-subdu ed-opening-ceremony-the-tokyo-summer-olympics-have-offic ially-kicked.

Fallon, K. (July 23, 2021). The Tokyo Olympics Opening Ceremony was depressing as hell. Daily Beast. Retrieved from https://www. thedailybeast.com/the-tokyo-olympics-opening-ceremony-wasdepressing-as-hell.

Fan, Y. 2010. Branding the nation: Towards a better understanding. Journal of Place Branding and Public Diplomacy 6 (2): 97-103.

Fowler, W. (August 6, 2021). Which nations have claimed their first-ever medals in Tokyo? NBC Olympics. Retrieved from https://www.nbcolympics.com/news/which-nations-have-claim ed-their-first-ever-medals-tokyo.

GamesBids. (n.d.). Past Olympic host election results. GamesBids. Retrieved from https://gamesbids.com/eng/past-bid-results/.

Gordon, A. (August 8, 2016). Olympic hospitality houses are a place to cry and party during the Games. Vice. Retrieved from https://www.vice.com/en/article/jp7g5x/olympic-hospi tality-houses-are-a-place-to-cry-and-party-during-the-games.

Grez, M. (2019). Nike Oregon Project to shut down following Alberto Salazar ban. CNN. Retrieved from https://www.cnn.com/2019/10/ 11/sport/nike-oregon-project-shut-down-alberto-salazar-spt-intl/ index.html.

Handelman, S. 2012. The Minds of Peace Experiment: A laboratory for people-to-people diplomacy. Israel Affairs 18 (1): 1-11. https:// doi.org/10.1080/13537121.2012.634278.

International Olympic Committee. (2014). Olympic Agenda 2020 20+20 Recommendations. International Olympic Committee. Retrieved from https://stillmed.olympics.com/media/Docum ent\%20Library/OlympicOrg/Documents/Olympic-Agenda-2020/ Olympic-Agenda-2020-20-20-Recommendations.pdf.

International Olympic Committee. (2020). The Olympic Charter. Lausanne, Switzerland: International Olympic Committee. Retrieved from https://stillmed.olympic.org/media/Document\%20Library/ OlympicOrg/General/EN-Olympic-Charter.pdf.

International Olympic Committee. (March 2021a). Olympic Marketing Fact File 2021 Edition. International Olympic Committee. Retrieved from https://stillmed.olympics.com/media/Documents/ International-Olympic-Committee/IOC-Marketing-And-Broad casting/IOC-Marketing-Fact-File-2021.pdf.

International Olympic Committee. (2021c). IOC Refugee Olympic Team Tokyo 2020. Olympics. Retrieved from https://olympics. com/ioc/refugee-olympic-team-tokyo-2020.

International Olympic Committee. (2021d). IOC extends opportunities for athlete expression during the Olympic Games Tokyo 2020. International Olympic Committee. Retrieved from https://olymp ics.com/ioc/news/ioc-extends-opportunities-for-athlete-expre ssion-during-the-olympic-games-tokyo-2020.

International Olympic Committee. (2021e). Olympic Agenda 2020+5 - 15 Recommendations. International Olympic Committee. Retrieved from https://stillmedab.olympic.org/media/Docum ent\%20Library/OlympicOrg/IOC/What-We-Do/Olympic-agenda/ Olympic-Agenda-2020-5-15-recommendations.pdf.

International Olympic Committee. (August 8, 20201b). Olympic Solidarity inspires record number of NOCs to medal. Olympics. Retrieved from https://olympics.com/ioc/news/olympic-solid arity-inspires-record-number-of-nocs-to-medal?fbclid=IwAR0 wqyAooc66B 9106eBBcRMsIWjHdKgpPuscCbFH0JUSri5x orXNFAyVVZg.

Kuhn, A. (July 20, 2021). Toyota and other big Olympics sponsors are downplaying their ties to the Games. $n p r$. Retrieved from https:// www.npr.org/sections/tokyo-olympics-live-updates/2021/07/20/ 1018390493/toyota-and-other-big-olympics-sponsors-are-downp laying-their-ties-to-the-games.

Kwiatkowski, M. (July 27, 2021). Larry Nassar's abuse of gymnasts, including Simone Biles went back decades. Why it still matters in Tokyo. USA Today. Retrieved from https://www.usatoday.com/ story/sports/olympics/2021/07/27/usa-gymnastics-larry-nasserabuse-scandal-looms-over-tokyo-olympics/5375279001/.

McCurry, J. (June 10, 2021). 'Claims could run into billions': the interests at stake if Olympics in Japan were cancelled. The Guardian. Retrieved from https://www.theguardian.com/sport/2021/jun/10/ claims-could-run-into-billions-the-interests-at-stake-if-olympicsin-japan-were-cancelled.

Morgan, L. (September 8, 2021). North Korea banned from Beijing 2022 after IOC suspends NOC. Inside the Games. Retrieved from https://www.insidethegames.biz/articles/1112768/ioc-suspendsnorth-korea-noc-beijing2022.

Murray, S. 2018. Sports diplomacy: Origins, theory and practice, 2018. New York: Routledge.

Nolympics LA. (n.d.). Retrieved from https://nolympicsla.com/. 
Norlander, M. (August 8, 2021). Katie Ledecky makes history with 6th individual gold, cements Olympic icon status, and she'll be back in 2024. CBS Olympics. Retrieved from https://www.cbssports.com/ olympics/news/katie-ledecky-makes-history-with-6th-individualgold-cements-olympic-icon-status-and-shell-be-back-in-2024/.

Nye, J.S., Jr. 2004. Soft power: The means to success in world politics. New York: PublicAffairs.

Ordeix-Rigo, E., and J. Durate. 2009. From public diplomacy to corporate diplomacy: Increasing corporations' legitimacy and influence. American Behavioral Scientist 53 (4): 549-564. https://doi.org/ 10.1177/0002764209347630.

Palmer, D. (July 30, 2021). IJF praises Saudi Arabian for facing Israeli opponent at Tokyo 2020. Inside the Games. Retrieved from https://www.insidethegames.biz/articles/1110991/ judo-israel-saudi-arabia-bout.

Pigman, G.A. 2014. International sport and diplomacy's public dimension: Governments, sporting federations and the global audience. Diplomacy \&amp; Statecraft 25 (94): 94-114. https://doi.org/10. 1080/09592296.2014.873613.

Rich, M. (August 22, 2016). A morning surprise for Japan: Shinzo Abe as Super Mario. The New York Times. Retrieved from https:// www.nytimes.com/2016/08/23/world/asia/shinzo-abe-supermario-tokyo-rio-olympics.html.

Ronay, B. (August 8, 2021). Tokyo says goodbye to the Games with grace and sense of relief. The Guardian. Retrieved from https:// www.theguardian.com/sport/2021/aug/08/tokyo-says-goodb ye-to-the-games-with-grace-and-sense-of-relief.

Rosenberg, M. (July 23, 2021). Pandemic, protests loom over lackluster Opening Ceremony at Tokyo Olympics. Sports Illustrated. Retrieved from https://www.si.com/olympics/2021/07/23/openi ng-ceremony-tokyo-olympics-pandemic-protestors-empty-stadi um.

Reuters Staff. (September 13, 2021). Judo-Algerian Nourine gets 10-year ban for withdrawing from Olympics to avoid Israel. Reuters. Retrieved from https://www.reuters.com/article/judo-alger ia-sanctions-idAFL4N2QG1A0.

Staff Report (August 14, 2021). COVID-19 tracker: Tokyo logs over 5,000 new cases as number of severely ill patients continues to rise. The Japan Times. Retrieved from https://www.japantimes.co. jp/news/2021/08/14/national/japan-cases-wrap-august-14/.

The Japan Times. (August 13, 2021). First Japan case involving lambda COVID-19 variant linked to Olympics. The Japan Times. Retrieved from https://www.japantimes.co.jp/news/2021/08/13/ national/lambda-olympic-case/.

TMC. (July 23, 2021). COVID-19 Updates from the TMC - July 23, 2021. Tokyo Media Center. TMC Newsletter.

Tokyo 2020. (n.d.). Olympic medal table. Olympics. Retrieved from https://olympics.com/tokyo-2020/olympic-games/en/results/allsports/medal-standings.htm.

Tokyo 2020. (2021a). The Playbooks. Olympics. Retrieved from https:// olympics.com/tokyo-2020/en/games/tokyo-2020-playbooks/.
Tokyo 2020. (May 2021b). Media Handbook. Tokyo, Japan: The Tokyo Organising Committee of the Olympic and Paralympic Games.

Tokyo 2020. (July 2021c). Tokyo 2020 Olympic Games Opening Ceremony Media Guide. Tokyo 2020.

Tokyo 2020. (August 2021d). Tokyo 2020 Olympic Games Opening Ceremony Media Guide. Tokyo 2020.

Tokyo 2020. (June 30, 2021e). First Olympic Agora cultural hub opens in Tokyo. Olympics. Retrieved from https://olympics.com/tokyo2020/en/news/first-olympic-agora-cultural-hub-opens-in-tokyo.

Tokyo 2020. (2021f). Explore Japan. Olympics. Retrieved from https:// olympics.com/tokyo-2020/en/events/.

Trouillard, S. (July 28, 2021). Freedom-flavoured silver medal for Iranian-born judoka competing for Mongolia. France 24. Retrieved from https://www.france24.com/en/sport/20210728-tokyo-gamesfreedom-flavoured-silver-medal-for-iranian-born-judoka-compe ting-for-mongolia.

USADA. (October 10, 2021). Statement from USADA CEO Travis T. Tygart regarding The U.S. Postal Service Pro Cycling Team doping conspiracy. USADA. Retrieved from https://www.usada.org/ statement/statement-from-usada-ceo-travis-t-tygart-regarding-theu-s-postal-service-pro-cycling-team-doping-conspiracy/.

Zaccardi, N. (June 4, 2020). Gwendolyn Berry gets apology from USOPC CEO after reprimand for podium gesture. NBC Sports. Retrieved from https://olympics.nbcsports.com/2020/06/04/gwenberry-protest/

Zimbalist, A. 2016. Circus Maximus. Washington, D.C.: Brookings Institution Press.

Zirin, D., and Boykoff, J. (June 16, 2021). The IOC says the 2032 Olympics are coming to Brisbane. The Nation. Retrieved from https://www.thenation.com/article/society/ioc-brisbane-olymp ics-2032/.

Publisher's Note Springer Nature remains neutral with regard to jurisdictional claims in published maps and institutional affiliations.

Yoav Dubinsky (Ph.D., University of Tennessee, Knoxville), Instructor of Sports Business, Department of Marketing, Lundquist College of Business, University of Oregon. Dr Dubinsky's research interests include sports, country image, nation branding, and public diplomacy. Dr. Dubinsky has been focusing on the Olympic Movement for over a decade, including covering or researching the 2008, 2012, 2016, and 2020 Olympic Games as an accredited journalist from Beijing, London, Rio de Janeiro and Tokyo, and being involved with the International Olympic Academy in Olympia, Greece, as a student, a coordinator and a lecturer. 